\title{
Blood gas analysis, anion gap, and strong ion difference in horses treated with polyethylene glycol balanced solution (PEG 3350) or enteral and parenteral electrolyte solutions
}

\author{
Hemogasometria, anion gap e diferença de íons fortes em equinos tratados com solução balanceada \\ contendo polietilenoglicol (PEG 3350) ou soluções eletrolíticas enteral e parenteral \\ Cláudio Luís Nina Gomes ${ }^{\mathrm{I}}$ José Dantas Ribeiro Filho ${ }^{\mathrm{I}{ }^{*}}$ Rafael Resende Faleiros ${ }^{\mathrm{III}}$ \\ Fernanda Timbó D’el Rey DantasII Lincoln da Silva Amorim"I \\ Waleska de Melo Ferreira Dantas ${ }^{\text {II }}$
}

\section{ABSTRACT}

Large volumes of different electrolytes solutions are commonly used for ingesta hydration in horses with large colon impaction, but little is known about their consequences to blood acid-base balance. To evaluate the effects of PEG 3350 or enteral and parenteral electrolyte solutions on the blood gas analysis, anion gap and strong ion difference, five adult female horses were used in a $5 \times 5$ latin square design. The animals were divided in five groups and distributed to each of the following treatments: $\mathrm{NaCl}(0.9 \%$ sodium chloride solution); EES (enteral electrolyte solution), EES+LR (EES plus lactated Ringer's solution); PEG (balanced solution with PEG 3350) and PEG+LR (PEG plus lactated Ringer's solution). Treatments PEG or PEG + LR did not change or promoted minimal changes, while the EES caused a slight decrease in $\mathrm{pH}$, but its association with lactated Ringer's solution induced increase in AG and SID values, as well as caused hypernatremia. In turn, the treatment $\mathrm{NaCl}$ generated metabolic acidosis. PEG 3350 did not alter the acid-base balance. Despite it's slight acidifying effect, the enteral electrolyte solution (EES) did not cause clinically relevant changes.

Key words: Acid-base balance, cathartic, fluid therapy.

\section{RESUMO}

Grandes volumes de diferentes soluções eletrolíticas são comumente usados na hidratação da ingesta em equinos com compactação, mas pouco se sabe sobre suas consequências sobre o equilíbrio ácido base sanguíneo. Para avaliar os efeitos do PEG 3350 e soluções eletrolíticas enterais e parenterais sobre a hemogasometria, anion gap e diferença de íons fortes, foram utilizadas cinco fêmeas adultas em um quadrado latino 5x5. Os animais foram distribuídos em cinco grupos e submetidos a cada um dos seguintes tratamentos: solução $\mathrm{NaCl}$ (cloreto de sódio 0,9\%); EES (solução eletrolítica enteral); EES + RL (solução eletrolítica enteral mais Ringer lactato); PEG 3350 (solução balanceada com PEG 3350) e PEG + RL (PEG 3350 mais Ringer lactato). Os tratamentos PEG ou PEG + RL não alteraram ou promoveram alterações mínimas, enquanto a EES ocasionou discreta diminuição no $\mathrm{pH}$, mas sua associação com Ringer lactato induziu o aumento nos valores do AG e DIF, além de ocasionar hipernatremia. Por sua vez, o tratamento $\mathrm{NaCl}$ resultou em acidose metabólica hiperclorêmica. O PEG 3350 não alterou o equilíbrio ácido base. Apesar do seu discreto efeito acidificante, a solução eletrolítica enteral (EES) não promoveu alteração clínica relevante.

Palavras-chave: Equilíbrio ácido base, catártico, hidratação.

\section{INTRODUCTION}

Large intestine impaction is one of the most frequent causes of colic in horse (DABAREINER \& WHITE, 1995; RIBEIRO FILHO et al., 2012). Traditionally, treatment has been based on the administration of large volume of intravenous electrolyte solution in order to promote hydration of ingesta and faeces. Among the solutions for parenteral use in horses, lactated Ringer's and $0.9 \%$ sodium chloride are probably the most common solutions used worldwide. Lactated Ringer's solution (LR) has a polyionic composition similar to plasma, and is therefore commonly administered for general use (ROSE, 1981). LR has a slight alkalinizing effect in blood, which has already been described in horses (RIBEIRO FILHO et al., 2007) and dogs (RIBEIRO FILHO et al., 2008). On the other hand, the $0.9 \%$

'Departamento de Clínicas Veterinárias, Universidade Estadual do Maranhão (UEMA), Maranhã, MA, Brasil.

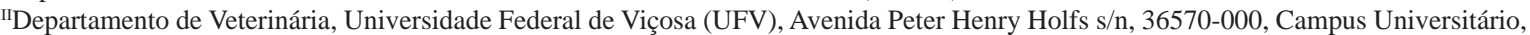
Viçosa, MG, Brasil. E-mail: dantas@ufv.br.*Autor para correspondência.

IIIDepartamento de Clínica e Cirurgia Veterinárias, Universidade Federal de Minas Gerais (UFMG), Minas Gerais, MG, Brasil.

$$
\begin{gathered}
\text { Received 06.28.12 Approved 09.24.13 Returned by the author 03.25.14 } \\
\text { CR-2012-0458.R3 }
\end{gathered}
$$


sodium chloride solution can lead to hyperchloremic metabolic acidosis and has been indicated to most animals suffering from dehydration associated with sodium and chloride loss (ROSE, 1981; MATHEWS, 1998).

More recently, enteral electrolyte solution (EES) therapy has gain popularity as a direct and effective way to promote hydration of the ingesta (LOPES et al., 2002; RIBEIRO FILHO et al., 2012). Enteral fluids are also quickly absorbed through intestine and expand blood volume, rehydrate the tissues and correct electrolytes imbalances (RIBEIRO FILHO et al., 2007). Another advantage is the possibility of the enteral solution to be formulated as needed by the patient, as well as it's low cost. Despite its advantages, the enteral technique might also cause electrolyte and acid-base imbalances, depending on its composition (RIBEIRO FILHO et al., 2009).

Laxatives are substances that increase defecation frequency, fecal bulk, or alter the fecal consistency (CLARK \& BECHT, 1987), and can also be used to treat large intestine impactions. Polyethylene glycol (PEG 3350) is an effective osmotic laxative used in humans (CLEVELAND et al., 2001). It has a high molecular weight, does not suffer tissue or bacterial degradation, and acts as a pure osmotic agent, being released quantitatively in the colon (SCHILLER, 1999). In Brazil, was launched recently the Munvilax ${ }^{\mathrm{R}}$, a laxative of polyethylene glycol 3350. In commercially available products for laxative use, PEG 3350 is combined with balanced amounts of sodium bicarbonate, sodium chloride and potassium in such way that the exchange of water and electrolytes with the blood is minimal (ATTAR et al., 1999), reducing the risk of dehydration that can occur with other osmotic laxatives. To our knowledge, there are currently no studies evaluating the use of this substance in veterinary medicine, with the exception of an experiment using cats (TAM et al., 2011). The aim of this study was to evaluate the effects of a standard PEG 3350 solution compared with other electrolyte solutions given by intravenous and enteral routes, on the acid-base balance, anion gap and strong ion difference.

\section{MATERIAL AND METHODS}

Five female crossbred horses aged between five and nineteen years (mean $=12.5$ years), with good body condition $392 \pm 18 \mathrm{~kg}$ (mean \pm sd) were used. Mares had no history of intestinal disease in the last six months and were considered healthy based on physical examination, blood biochemistry and cell counts, and urinalysis. Ten days prior to the study, horses were dewormed (Ivermectin + Praziquantel ${ }^{\mathrm{a}}$,
PO) and received a deltamethrin spray bath (0.025\%) for ticks and flies control. During all the research period horses were kept in individual stalls and were fed with commercial concentrated ${ }^{\mathrm{b}}$ ( $1 \%$ of bwt daily, divided into two meals), Tifton 85 hay ( $2 \%$ of bwt daily, two meals), 50g/day of a minerals mixture ${ }^{c}$ and water "ad libitum". During the treatment period horses were fasted (T0h to T12h).

Each mare was submitted to 5 different treatments in a $5 \times 5$ Latin square design, considering the effects period, treatment and time with the animal effect being random. The treatments were as follow: $\mathrm{NaCl}$ - received $0.9 \%$ sodium chloride solution $^{\mathrm{d}}$ administered intravenously in a dose of $15 \mathrm{~mL} \mathrm{~kg} \mathrm{~kg}^{-1}$ for 12 hours under continuous flux. Osmolarity and $\mathrm{pH}$ of the solution: $309.80 \mathrm{mMol}$ $\mathrm{L}^{-1}$ and 5.60, respectively. EES - received enteral electrolyte solution containing $6 \mathrm{~g} \mathrm{NaCl} ; 0.5 \mathrm{~g} \mathrm{KCl}$; $1 \mathrm{~g}$ calcium gluconate; $0.3 \mathrm{~g}$ magnesium pidolate $\mathrm{e}^{\mathrm{e}} \mathrm{5g}$ maltodextrin in $1.000 \mathrm{~mL}$ of water, via small-caliber nasogastric tube in a dose of $15 \mathrm{~mL} \mathrm{~kg}^{-1} \mathrm{~h}^{-1}$ for 12 hours under continuous flux. Osmolarity and $\mathrm{pH}$ of the solution: $321.14 \mathrm{mMol} \mathrm{L}^{-1}$ and 7.2, respectively. EES+LR - received enteral electrolyte solution (same composition of EES treatment), via small-caliber nasogastric tube in a dose of $7.5 \mathrm{~mL} \mathrm{~kg} \mathrm{~kg}^{-1} \mathrm{~h}^{-1}$ for 12 hours under continuous flux, plus $7.5 \mathrm{~mL} \mathrm{~kg}^{-1} \mathrm{~h}^{-1}$ of lactated Ringer's solution administered intravenously for 12 hours under continuous flux. PEG - a single dose of PEG $3350^{\mathrm{f}}\left(1.5 \mathrm{~g} \mathrm{~kg}^{-1}\right)$ diluted in five liters of water given via nasogastric tube. Osmolarity and $\mathrm{pH}$ of the solution: $252.66 \mathrm{mMol} \mathrm{L}^{-1}$ and 8.65 , respectively. PEG+LR - a single dose of PEG 3350 $\left(1.5 \mathrm{~g} \mathrm{~kg}^{-1}\right)$ diluted in five liters of water, given via nasogastric tube, plus $15 \mathrm{~mL} \mathrm{~kg}^{-1} \mathrm{~h}^{-1}$ of lactated Ringer's solution administered intravenously for 12 hours under continuous flux. Osmolarity and $\mathrm{pH}$ of the solution of lactated Ringer's: $272.22 \mathrm{mMol} \mathrm{L}^{-1}$ and 6.75 , respectively. The interval between treatment periods was 14 days.

Baseline blood samples for blood gas and biochemical tests were taken immediately before the start of the treatment (T0h) and 6 (T6h), 12 (T12h), 24 (T24h) and 48 (T48h) hours after treatment beginning. For biochemistry analysis, samples were collected aseptically via jugular venipuncture, and stored in vials with sodium fluoride or without anticoagulant ${ }^{\mathrm{g}}$. Sodium and potassium serum concentrations were measure using flame photometry ${ }^{\mathrm{h}}$ while a multi-biochemical analyzer ${ }^{j}$ was used to measure serum chloride and plasma L-lactate concentrations.

For blood gas analysis, samples were collected anaerobically via jugular venipuncture 
using previously heparinized ${ }^{\mathrm{k}} 3 \mathrm{~mL}$ disposable plastic syringes and 30x7 needles. A blood gas analyzer ${ }^{l}$ was used to obtain the following variables: $\mathrm{pH}_{\text {(v) }}$, oxygen partial pressure - $\mathrm{pO}_{2(\mathrm{v})}$, carbon dioxide partial pressure - $\mathrm{pCO}_{2(\mathrm{v})}$, carbon dioxide total concentration - $\mathrm{tCO}_{2(\mathrm{v})}$, plasma bicarbonate concentration - $\mathrm{CHCO}_{3(\mathrm{v})}^{-}$and base excess - $\mathrm{BE}_{(\mathrm{v})}$. The strong ion difference (SID) and anion gap (AG) were calculated using the respective formulas: $\mathrm{SID}(\mathrm{mMol})=\left(\mathrm{Na}^{+}+\mathrm{K}^{+}\right)-\left(\mathrm{Cl}^{-}+\right.$lactate $) ; \mathrm{AG}(\mathrm{mMol})=$ $\left(\mathrm{Na}^{+}+\mathrm{K}^{+}\right)-\left(\mathrm{Cl}^{-}+\mathrm{HCO}_{3}^{-}\right)(\mathrm{CONSTABLE}, 1999)$.

Data was analyzed using specific statistical software (SAEG UFV-01.09.2007). ANOVA was used to compare the effect of treatments within each time and the effect of times within each treatment. Post-hoc comparisons were made using the Tukey test. The nonparametric Kruskal-Wallis test was used when data did not meet the assumptions of normality or equality of variance. The null hypothesis was rejected when $\mathrm{P}<0.05$.

\section{RESULTS AND DISCUSSION}

Our results showed that therapeutic protocols commonly used for ingesta hydration using intravenous or enteral routes can produce significant changes in the blood acid-base and electrolyte balances in normal horses. On the other hand, the proposed protocol using PEG 3350 solution alone administered in a single dose did not alter any of the studied variables.

An important change in the physiologic balance occurred in $\mathrm{NaCl}$ group, where hyperchloremia (Table 1) with a concomitant decrease in blood $\mathrm{pH}$ were detected at the end of electrolyte solution administration (T12h). Normal saline $(0.9 \% \mathrm{NaCl}$ solution) has higher levels of chloride compared to plasma (MATHEUS, 1998) and administration of large volumes can cause changes in acid-base balance, i.e. hyperchloremic metabolic acidosis (CONSTABLE, 1999; PROUGH \& BIDANI, 1999). Metabolic acidosis is traditionally divided into hyperchloremic (normal anion gap) and normochloremic (high anion gap) based on the anion gap and chloride (DeMORAIS \& BIONDO, 2012). Chloride is the most prevalent strong anion in the ECF. At a constant $\left[\mathrm{Na}^{+}\right]$, an increase in $\left[\mathrm{Cl}^{-}\right]$ decreases SID causing hyperchloremic acidosis. The effects of increasing $\left[\mathrm{Cl}^{-}\right]$without changing $\left[\mathrm{Na}^{+}\right]$can be understood when considering a fluid with an SID $=0$ (e.g., $0.9 \% \mathrm{NaCl}$ where $\left[\mathrm{Na}^{+}\right]=\left[\mathrm{Cl}^{-}\right]$and thus SID $\left.=\left[\mathrm{Na}^{+}\right]-\left[\mathrm{Cl}^{-}\right]=0\right)(\mathrm{CONSTABLE}, 2003)$, producing the occurrence of the acidifying effect of $0.9 \% \mathrm{NaCl}$, which can be seen in tables 1 and 2 .
The traditional approaches for assessing blood gas analysis also demonstrated by the presence of metabolic acidosis in the animals of $\mathrm{NaCl}$ group, ie a decrease in $\mathrm{pH}, \mathrm{tCO}_{2}, \mathrm{HCO}_{3}$ and base excess values compared with baseline was seen in animals of that group at $\mathrm{T} 12 \mathrm{~h}$ (Table 1 and 2), which was also coincident with a similar increase in the chloride levels (Table 3). The decrease in the concentration of $\mathrm{HCO}_{3}$, and thus in the base excess, occurred due to the compensation mechanism, when there is an increase of the chloride anion, the body increases the excretion of bicarbonate anion. Increases in serum chloride concentrations in horses after the enteral administration of electrolyte solutions were recorded by others (ECKE et al., 1998; ALVES et al., 2005). For other treatments of this research, despite the decrease in $\mathrm{pH}$ values, $\mathrm{tCO}_{2}, \mathrm{HCO}_{3}^{-}$ and base excess did not detect the presence of metabolic acidosis as can be seen in tables 1 and 2 .

In $\mathrm{T} 12 \mathrm{~h}, \mathrm{pCO}_{2}$ values declined $(\mathrm{P}<0.05)$ in treatments EES, compared to $\mathrm{T} 6 \mathrm{~h}$, and $\mathrm{NaCl}$, compared to T0h, with the lowest average for animals treated with $\mathrm{NaCl}$ (Table 2). According to CARLSON \& BRUSS (2008), $\mathrm{pCO}_{2}$ decreases as a compensatory response of the respiratory component to metabolic acidosis. Therefore, in the same way that EES treatment caused a decrease in $\mathrm{pH}, \mathrm{tCO}_{2}, \mathrm{HCO}_{3}$ and base excess, it also reduced $\mathrm{pCO}_{2}$, which recovered quickly after treatment completion. Emphasizing that despite the decrease, all variables remained within the reference, even in animals of $\mathrm{NaCl}$ treatment. In turn, there was no difference between treatments either in treatments over time nor in the values of $\mathrm{pO}_{2}$.

When using enteral electrolyte solutions containing carbohydrates as an energy source, there is the possibility of these substances to predispose to the onset of acidosis. This is because sugars and starches undergo bacterial metabolism in the gastrointestinal tract, generating organic acids (ZHANG et al., 2003). Among these acids are the isomers L-lactate and D-lactate (FALL \& SZERLIP, 2005). Once absorbed in the digestive tract, the D-lactate metabolism is carried out at a very slow rate (FALL \& SZERLIP, 2005), because mammals have little specific mechanisms for metabolizing D-lactate and the accumulation in the blood can cause metabolic acidosis (EWASCHUK et al., 2005). But the results of this experimental study show that the maltodextrin $\left(10 \mathrm{~g} \mathrm{~L}^{-1}\right)$ present in treatments ESS and ESS+LR did not cause the appearance of this adverse effect.

As expressed in table 3 , the values of lactate remained within the reference (KANEKO et al., 2008) in animals of all treatments, despite the difference detected between treatments at 
T6h and $\mathrm{T} 12 \mathrm{~h}$ and in treatments throughout the experimental phase, making them without clinical significance. The D-lactate was not measured in this study, however its level can be estimate through the anion gap (AG). The AG reference values for horses range from 5 to $16.2 \mathrm{mMol} \mathrm{L}^{-1}$ (CARLSON \& BRUSS, 2008). It is used primarily to identify metabolic acidosis, confirm the mixed disturbances and prognosis (GOSSETT et al., 1987). Higher rates to the reference range indicate metabolic acidosis due to an increase in unmeasured anions, especially the D-lactate, as occurs in lactic acidosis, determining the bicarbonate decrease (DeMORAIS \& DiBARTOLA, 1993). As significant changes in the AG values were not detected in the EES group, corroborates the assertion that the maltodextrin administered at a dose of $10 \mathrm{~g} \mathrm{~L}^{-1}$ does not cause the onset of metabolic acidosis (Table 1).

The animals receiving EES+RL treatment showed an important increase in sodium concentration at $\mathrm{T} 12 \mathrm{~h}(\mathrm{P}<0.05)$. Hypernatremia is characterized by a value of serum sodium exceeding $147 \mathrm{mEq} \mathrm{L}^{-1}$ (STEWART, 1998). Although water loss through dehydration is considered the main cause of hypernatremia, it can also be caused by excessive sodium intake through hydration with the electrolyte solutions, such as sodium bicarbonate administered intravenously and also with $0.9 \% \mathrm{NaCl}$ solution given enterally (BARBOSA \& SZTAJNBOK, 1999). The increase of sodium concentration in the EES+LR at T12h $(\mathrm{P}<0.05)$ can be attributed to the fact that animals received sodium from three sources:

Table 1 - Means and standard deviations values of $\mathrm{cHCO}_{3}^{-}\left(\mathrm{mMol} \mathrm{L}^{-1}\right)$, BE $\left(\mathrm{mMol} \mathrm{L}^{-1}\right)$, Anion Gap $\left(\mathrm{mMol} \mathrm{L}^{-1}\right)$ and SID $\left(\mathrm{mMol} \mathrm{L}^{-1}\right)$, in venous blood (v) of five horses treated with PEG, PEG+LR, EES, EES+LR, and NaCl in pretreatment (T0h), treatment (T6h and T12h) and post-treatment (24h and T48h) periods.

\begin{tabular}{|c|c|c|c|c|c|}
\hline \multirow[t]{2}{*}{ Treatment } & \multicolumn{5}{|c|}{---------------------------------------------------------------------------Period---. } \\
\hline & T0h & T6h & $\mathrm{T} 12 \mathrm{~h}$ & $\mathrm{~T} 24 \mathrm{~h}$ & T48h \\
\hline & \multicolumn{5}{|c|}{-"-c-} \\
\hline PEG & $28.96 \pm 1.86^{\text {Аа }}$ & $27.28 \pm 1.65^{\mathrm{Aa}}$ & $26.70 \pm 1.21^{\text {Аa }}$ & $29.14 \pm 1.23^{\mathrm{Aa}}$ & $28.36 \pm 1.23^{\mathrm{Aa}}$ \\
\hline PEG+LR & $27.66 \pm 1.53^{\mathrm{Aab}}$ & $26.62 \pm 0.33^{\text {Aab }}$ & $25.98 \pm 1.27^{\mathrm{ABb}}$ & $29.30 \pm 1.25^{\mathrm{Aa}}$ & $27.96 \pm 1.87^{\mathrm{Aab}}$ \\
\hline EES & $28.60 \pm 0.82^{\text {Аа }}$ & $26.06 \pm 2.35^{\mathrm{ABab}}$ & $24.88 \pm 0.95^{\mathrm{ABb}}$ & $26.54 \pm 1.33^{\text {Bab }}$ & $27.32 \pm 1.23^{\text {Aab }}$ \\
\hline $\mathrm{EES}+\mathrm{LR}$ & $29.26 \pm 1.11^{\mathrm{Aa}}$ & $25.34 \pm 1.76^{\mathrm{ABb}}$ & $25.60 \pm 1.16^{\mathrm{ABb}}$ & $28.24 \pm 1.54^{\mathrm{ABab}}$ & $28.24 \pm 1.89^{\text {Aab }}$ \\
\hline $\mathrm{NaCl}$ & $28.52 \pm 0.78^{\mathrm{Aab}}$ & $22.42 \pm 0.80^{\mathrm{Bbc}}$ & $21.02 \pm 1.66^{\mathrm{Bc}}$ & $27.94 \pm 0.87^{\text {ABabc }}$ & $28.82 \pm 1.19^{\mathrm{Aa}}$ \\
\hline PEG & $4.10 \pm 1.59^{\mathrm{Aa}}$ & $2.50 \pm 1.45^{\mathrm{Aa}}$ & $1.84 \pm 0.98^{\text {Aa }}$ & $3.92 \pm 0.83^{\mathrm{Aa}}$ & $2.98 \pm 1.24^{\mathrm{Aa}}$ \\
\hline PEG+LR & $3.32 \pm 1.34^{\mathrm{Aab}}$ & $1.68 \pm 0.39^{\mathrm{Ab}}$ & $0.82 \pm 0.92^{\mathrm{ABb}}$ & $4.28 \pm 1.04^{\mathrm{Aa}}$ & $3.50 \pm 1.60^{\text {Aab }}$ \\
\hline EES & $4.10 \pm 0.74^{\mathrm{Aa}}$ & $-0.14 \pm 1.29^{\mathrm{ABb}}$ & $-0.52 \pm 0.80^{\mathrm{ABb}}$ & $1.52 \pm 1.13^{\mathrm{Bab}}$ & $2.30 \pm 1.33^{\text {Aab }}$ \\
\hline EES+LR & $4.52 \pm 1.34^{\mathrm{Aa}}$ & $0.24, \pm 1.72^{\mathrm{ABb}}$ & $0.72 \pm 2.04^{\mathrm{ABb}}$ & $3.46 \pm 1.25^{\mathrm{ABab}}$ & $3.04 \pm 1.04^{\text {Aab }}$ \\
\hline $\mathrm{NaCl}$ & $3.46 \pm 0.60^{\text {Aab }}$ & $-2.64 \pm 1.07^{\mathrm{Bbc}}$ & $-4.18 \pm 2.00^{\mathrm{Bc}}$ & $2.90 \pm 0.78^{\mathrm{ABabc}}$ & $3.72 \pm 1.00^{\mathrm{Aa}}$ \\
\hline PEG & $6.64 \pm 13.37^{\text {Аа }}$ & $17.38 \pm 6.95^{\mathrm{Aa}}$ & $\begin{array}{l}7.16 \pm 14.02^{\mathrm{ABa}} \\
\text {---Anion Gap- }\end{array}$ & $7.94 \pm 9.32^{\mathrm{Ba}}$ & $10.50 \pm 7.26^{\mathrm{ABa}}$ \\
\hline PEG+LR & $5.24 \pm 5.19^{\mathrm{Aa}}$ & $3.24 \pm 24.41^{\mathrm{Aa}}$ & $2.08 \pm 8.44^{\mathrm{Ba}}$ & $-1.58 \pm 6.93^{\mathrm{Ba}}$ & $4.54 \pm 12.34^{\mathrm{Ba}}$ \\
\hline EES & $12.60 \pm 5.65^{\mathrm{Aa}}$ & $1.38 \pm 8.52^{\mathrm{Aa}}$ & $5.42 \pm 14.49^{\mathrm{Ba}}$ & $2.00 \pm 7.37^{\mathrm{Ba}}$ & $-1.30 \pm 7.31^{\mathrm{Ba}}$ \\
\hline $\mathrm{EES}+\mathrm{LR}$ & $11.18 \pm 7.10^{\mathrm{Ab}}$ & $16.44 \pm 8.48^{\text {Aab }}$ & $30.16 \pm 14.70^{\text {Аа }}$ & $24.76 \pm 5.72^{\text {Aab }}$ & $22.50 \pm 7.83^{\text {Aab }}$ \\
\hline $\mathrm{NaCl}$ & $8.94 \pm 5.58^{\mathrm{Aa}}$ & $8.66 \pm 3.28^{\mathrm{Aa}}$ & $6.92 \pm 8.64^{\mathrm{Ba}}$ & $8.56 \pm 10.01^{\mathrm{Ba}}$ & $12.08 \pm 5.02^{\mathrm{ABa}}$ \\
\hline PEG & $35.06 \pm 12.56^{\text {Аа }}$ & $44.09 \pm 6.58^{\mathrm{Aa}}$ & $35.30 \pm 10.62^{\mathrm{Ba}}$ & $36.53 \pm 9.97^{\mathrm{ABa}}$ & $38.29 \pm 6.91^{\mathrm{ABa}}$ \\
\hline PEG+LR & $32.34 \pm 8.11^{\mathrm{Aa}}$ & $29.34 \pm 24.33^{\mathrm{Ba}}$ & $29.45 \pm 5.92^{\mathrm{Ba}}$ & $27.15 \pm 6.39^{\text {Ва }}$ & $31.94 \pm 12.33^{\mathrm{Ba}}$ \\
\hline EES & $40.63 \pm 5.58^{\mathrm{Aa}}$ & $26.80 \pm 6.84^{\mathrm{Ba}}$ & $29.68 \pm 14.31^{\mathrm{Ba}}$ & $26.01 \pm 6.43^{\mathrm{Ba}}$ & $25.44 \pm 6.86^{\mathrm{Ba}}$ \\
\hline EES+LR & $39.85 \pm 7.97^{\text {Аа }}$ & $41.19 \pm 8.51^{\mathrm{Aa}}$ & $55.15 \pm 15.43^{\mathrm{Aa}}$ & $52.40 \pm 5.33^{\mathrm{Aa}}$ & $50.14 \pm 8.50^{\mathrm{Aa}}$ \\
\hline $\mathrm{NaCl}$ & $36.91 \pm 5.19^{\text {Aab }}$ & $30.50 \pm 3.83^{\text {Bab }}$ & $27.33 \pm 3.67^{\mathrm{Bb}}$ & $35.90 \pm 9.64^{\mathrm{ABab}}$ & $40.25 \pm 5.33^{\text {Aba }}$ \\
\hline
\end{tabular}

Means in the same column followed by equal capital letters and in the same row followed by equal lowercases letters do not differ at $5 \%$ level of probability by Tukey test.

PEG (Polyethylene glycol)

PEG+LR (PEG plus lactated Ringer' s solution)

EES (enteral electrolyte solution)

EES+LR (EES plus lactated Ringer' s solution)

$\mathrm{NaCl}$ ( $0.9 \%$ sodium chloride solution) 
the EES with $6 \mathrm{~g} \mathrm{~L}^{-1}$ of sodium chloride, lactated Ringer's solution containing $6 \mathrm{~g}$ of sodium chloride and $3 g$ of sodium lactate. The sum of them yielded in sodium concentration of $232.2 \mathrm{mMol} \mathrm{L}^{-1}$, which is higher than plasma's $\left(139 \pm 3.5 \mathrm{mMol} \mathrm{L}{ }^{-1}\right)$, resulting hypernatremia after their administration. As horses had access to water and food after the hydration phase (T24h and T48h), there was a gradual decrease in serum sodium during this time in animals of this group. Other study using isotonic enteral solution also reported hypernatremia due to the use of more than one sodium source (ALVES et al., 2005).

The hypernatremia observed in animals in the EES+RL at T12h was concomitant with the increase in the values of AG and $\operatorname{SID}(\mathrm{P}<0.05)$ at time 12 hours (Table 1$)$. This increase was caused by the presence of high serum sodium concentration due to the composition of electrolyte solutions used in such treatment. As the AG and SID were calculated by the equations: $\mathrm{AG}=\left(\mathrm{Na}^{+}+\mathrm{K}^{+}\right)-\left(\mathrm{Cl}^{-}+\mathrm{HCO}_{3}^{-}\right)$and $\mathrm{SID}=\left(\mathrm{Na}^{+}\right.$ $\left.+\mathrm{K}^{+}\right)-\left(\mathrm{Cl}^{-}+\right.$lactate), the increase in the concentration of serum sodium, explained above, determined the elevation of both values. Since the change in AG value was not commensurate with bicarbonate's (Table 1) in the same period (T12h), one should suspect the presence of mixed disorders as quoted CARLSON \& BRUSS (2012).

The treatments had no effect on serum potassium values that have remained unchanged throughout the experimental phase and within the reference range (KANEKO et al., 2008).

Although the protocol using PEG 3350 balanced solution (PEG) alone did not alter any of the

Table 2 - Means and standard deviations values of $\mathrm{pH}, \mathrm{pO}_{2}(\mathrm{mmHg}), \mathrm{pCO}_{2}(\mathrm{mmHg})$ and $\mathrm{tCO}_{2}$ (mMol $\left.\mathrm{L}^{-1}\right)$ in venous blood (v) of five horses treated with PEG, PEG+LR, EES, EES+LR, and $\mathrm{NaCl}$ in pretreatment (T0h), treatment (T6h and T12h) and post-treatment (24h and T48h) periods.

\begin{tabular}{|c|c|c|c|c|c|}
\hline Treatment & T0h & T6h & $\mathrm{T} 12 \mathrm{~h}$ & $\mathrm{~T} 24 \mathrm{~h}$ & T48h \\
\hline & & & --pH---------- & & \\
\hline PEG & $7.41 \pm 0.01^{\mathrm{Aa}}$ & $7.42 \pm 0.01^{\mathrm{Aa}}$ & $7.41 \pm 0.01^{\mathrm{Aa}}$ & $7.41 \pm 0.02^{\mathrm{Aa}}$ & $7.40 \pm 0.03^{\mathrm{Aa}}$ \\
\hline PEG+LR & $7.42 \pm 0.02^{\mathrm{Aa}}$ & $7.41 \pm 0.02^{\mathrm{ABa}}$ & $7.40 \pm 0.01^{\mathrm{ABa}}$ & $7.41 \pm 0.01^{\mathrm{Aa}}$ & $7.40 \pm 0.02^{\mathrm{Aa}}$ \\
\hline EES & $7.43 \pm 0.02^{\mathrm{Aa}}$ & $7.37 \pm 0.02^{\mathrm{CBb}}$ & $7.38 \pm 0.01^{\mathrm{ABb}}$ & $7.40 \pm 0.02^{\text {Aab }}$ & $7.41 \pm 0.01^{\text {Aab }}$ \\
\hline EES+LR & $7.42 \pm 0.02^{\mathrm{Aa}}$ & $7.39 \pm 0.02^{\mathrm{ACa}}$ & $7.40 \pm 0.02^{\mathrm{Aa}}$ & $7.42 \pm 0.02^{\mathrm{Aa}}$ & $7.40 \pm 0.02^{\mathrm{Aa}}$ \\
\hline $\mathrm{NaCl}$ & $7.41 \pm 0.01^{\mathrm{Aab}}$ & $7.35 \pm 0.03^{\mathrm{Cb}}$ & $7.35 \pm 0.04^{\mathrm{Bb}}$ & $7.42 \pm 0.02^{\mathrm{Aab}}$ & $7.42 \pm 0.07^{\mathrm{Aa}}$ \\
\hline PEG & $31,52 \pm 1,80^{\mathrm{Ba}}$ & $35,50 \pm 5,35^{\mathrm{Aa}}$ & $\begin{array}{l}-\mathrm{pO}_{2}--------- \\
34,04 \pm 2,01^{\mathrm{Aa}}\end{array}$ & $33,04 \pm 2,93^{\mathrm{Aa}}$ & $35,08 \pm 4,69^{\text {Aа }}$ \\
\hline PEG+LR & $36,10 \pm 2,64^{\mathrm{ABa}}$ & $36,38 \pm 5,30^{\text {Аа }}$ & $32,12 \pm 3,29^{\mathrm{Aa}}$ & $32,80 \pm 3,37^{\mathrm{Aa}}$ & $34,32 \pm 4,21^{\text {Aa }}$ \\
\hline EES & $36,50 \pm 2,93^{\mathrm{Aa}}$ & $39,64 \pm 4,85^{\text {Аа }}$ & $36,66 \pm 4,16^{\text {Аа }}$ & $36,40 \pm 3,90^{\mathrm{Aa}}$ & $36,34 \pm 4,51^{\mathrm{Aa}}$ \\
\hline EES+LR & $36,74 \pm 1,26^{\text {Аа }}$ & $34,78, \pm 4,51^{\mathrm{Aa}}$ & $36,12 \pm 3,90^{\text {Аа }}$ & $33,22 \pm 5,78^{\mathrm{Aa}}$ & $33,84 \pm 3,03^{\mathrm{Aa}}$ \\
\hline $\mathrm{NaCl}$ & $35,62 \pm 3,19^{\mathrm{ABa}}$ & $37,50 \pm 1,84^{\mathrm{Aa}}$ & $35,80 \pm 4,91^{\mathrm{Aa}}$ & $30,88 \pm 5,68^{\mathrm{Aa}}$ & $34,26 \pm 3,67^{\mathrm{Aa}}$ \\
\hline PEG & $47.98 \pm 4.43^{\mathrm{Aa}}$ & $43.24 \pm 2.46^{\mathrm{Aa}}$ & $\begin{array}{l}-\mathrm{pCO}_{2}------ \\
43.14 \pm 2.90^{\mathrm{Aa}}\end{array}$ & $47.14 \pm 3.60^{\mathrm{Aa}}$ & $47.10 \pm 4.15^{\mathrm{Aa}}$ \\
\hline PEG+LR & $44.68 \pm 1.91^{\mathrm{Aa}}$ & $43.30 \pm 1.70^{\mathrm{Aa}}$ & $43.20 \pm 2.50^{\mathrm{Aa}}$ & $45.88 \pm 2.43^{\mathrm{Aa}}$ & $44.48 \pm 1.82^{\mathrm{Aa}}$ \\
\hline EES & $44.04 \pm 1.27^{\mathrm{Aab}}$ & $46.70 \pm 1.66^{\mathrm{Aa}}$ & $42.90 \pm 0.68^{\mathrm{Ab}}$ & $44.04 \pm 3.04^{\mathrm{Aab}}$ & $44.16 \pm 1.03^{\text {Aab }}$ \\
\hline $\mathrm{EES}+\mathrm{LR}$ & $45.76 \pm 0.75^{\text {Aab }}$ & $42.82 \pm 2.95^{\mathrm{Aab}}$ & $42.06 \pm 3.18^{\mathrm{Ab}}$ & $44.96 \pm 2.27^{\text {Aab }}$ & $46.68 \pm 1.90^{\mathrm{Aa}}$ \\
\hline $\mathrm{NaCl}$ & $45.52 \pm 1.62^{\mathrm{Aa}}$ & $42.60 \pm 3.10^{\mathrm{Aab}}$ & $39.02 \pm 2.16^{\mathrm{Ab}}$ & $44.64 \pm 3.20^{\mathrm{Aa}}$ & $45.48 \pm 1.40^{\mathrm{Aa}}$ \\
\hline PEG & $30,92 \pm 1,99^{\text {Аа }}$ & $28,62 \pm 1,69^{\mathrm{Aa}}$ & $\begin{array}{c}--\mathrm{tCO}_{2}-------- \\
28,04 \pm 1,32^{\mathrm{Aa}}\end{array}$ & $30,58 \pm 1,32^{\mathrm{Aa}}$ & $29,80 \pm 1,27^{\mathrm{Aa}}$ \\
\hline PEG+LR & $29,38 \pm 1,54^{\text {Aab }}$ & $27,92 \pm 0,37^{\text {Aab }}$ & $27,30 \pm 1,34^{\mathrm{ABb}}$ & $30,70 \pm 1,29^{\mathrm{Aa}}$ & $29,32 \pm 1,87^{\text {Aab }}$ \\
\hline EES & $30,18 \pm 0,79^{\text {Аа }}$ & $26,86 \pm 1,68^{\mathrm{ABb}}$ & $25,98 \pm 0,68^{\mathrm{ABb}}$ & $27,94 \pm 1,32^{\mathrm{Bab}}$ & $28,66 \pm 1,27^{\text {Aab }}$ \\
\hline EES+LR & $30,84 \pm 1.02^{\mathrm{Aa}}$ & $26,72 \pm 1,88^{\mathrm{ABb}}$ & $28,88 \pm 5,21^{\text {Aab }}$ & $29,68 \pm 1,67^{\mathrm{ABab}}$ & $29,70 \pm 1,19^{\text {Aab }}$ \\
\hline $\mathrm{NaCl}$ & $29,92 \pm 0,80^{\mathrm{Aa}}$ & $24,48 \pm 1,81^{\mathrm{Bab}}$ & $22,26 \pm 1,59^{\mathrm{Bb}}$ & $29,32 \pm 0,94^{\mathrm{ABab}}$ & $30,22 \pm 1,19^{\mathrm{Aa}}$ \\
\hline
\end{tabular}

Means in the same column followed by equal capital letters and in the same row followed by equal lowercases letters do not differ at $5 \%$ level of probability by Tukey test.

PEG (Polyethylene glycol)

PEG+LR (PEG plus lactated Ringer' s solution)

EES (enteral electrolyte solution)

EES+LR (EES plus lactated Ringer's solution)

$\mathrm{NaCl}$ ( $0.9 \%$ sodium chloride solution) 


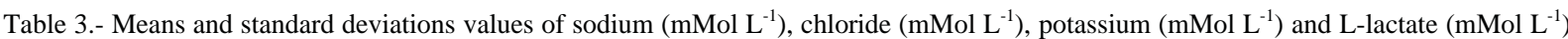
serum of five horses treated with PEG, PEG+LR, EES, EES+LR and $\mathrm{NaCl}$ in pretreatment (T0h), treatment (T6h and T12h) and post-treatment (24h and T48h) periods.

\begin{tabular}{|c|c|c|c|c|c|}
\hline \multirow[t]{2}{*}{ Treatment } & \multicolumn{5}{|c|}{---Period------ } \\
\hline & TOh & T6h & $\mathrm{T} 12 \mathrm{~h}$ & T24h & T48h \\
\hline & \multicolumn{5}{|c|}{ 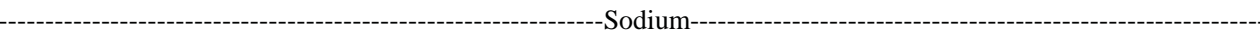 } \\
\hline PEG & $141,20 \pm 15,65^{\text {Aa }}$ & $149,20 \pm 6,68^{\mathrm{Aa}}$ & $140,80 \pm 11,03^{\mathrm{ABa}}$ & $142,80 \pm 9,18^{\mathrm{ABa}}$ & $142,20 \pm 8,55^{\mathrm{ABa}}$ \\
\hline PEG+LR & $137,40 \pm 8,88^{\mathrm{Aa}}$ & $137,60 \pm 21,35^{\text {Aa }}$ & $138,40 \pm 5,13^{\mathrm{ABa}}$ & $133,60 \pm 5,18^{\mathrm{Ba}}$ & $137,60 \pm 11,33^{\mathrm{ABa}}$ \\
\hline EES & $142,40 \pm 4,66^{\mathrm{Aa}}$ & $132,60 \pm 7,83^{\mathrm{Aa}}$ & $137,40 \pm 13,50^{\mathrm{Ba}}$ & $130,40 \pm 6,23^{\mathrm{Ba}}$ & $128,00 \pm 6,63^{\mathrm{Ba}}$ \\
\hline EES+LR & $143,20 \pm 7,60^{\mathrm{Ab}}$ & $148,20 \pm 6,30^{\text {Aab }}$ & $162,80 \pm 3,77^{\mathrm{Aa}}$ & $157,20 \pm 7,05^{\text {Aab }}$ & $152,80 \pm 8,78^{\mathrm{Aab}}$ \\
\hline $\mathrm{NaCl}$ & $139,80 \pm 5,07^{\text {Аa }}$ & $139,40 \pm 3,58^{\mathrm{Aa}}$ & $138,80 \pm 4,15^{\mathrm{ABa}}$ & $141,60 \pm 8,68^{\mathrm{ABa}}$ & $142,00 \pm 4,53^{\mathrm{ABa}}$ \\
\hline PEG & $108,90 \pm 4,33^{\text {Аa }}$ & $108,56 \pm 2,24^{\mathrm{Aa}}$ & $\begin{array}{l}108,56 \pm 2,22^{\mathrm{Ba}} \\
\text {----Chloride--- }\end{array}$ & $109,52 \pm 2,03^{\text {Aa }}$ & $107,28 \pm 4,10^{\mathrm{Aa}}$ \\
\hline PEG+LR & $109.94 \pm 5,87^{\mathrm{Aa}}$ & $111,04 \pm 3,38^{\mathrm{Aa}}$ & $111,78 \pm 1,31^{\mathrm{ABa}}$ & $109,60 \pm 1,40^{\mathrm{Aa}}$ & $108,80 \pm 1,61^{\mathrm{Aa}}$ \\
\hline EES & $104,58 \pm 1,03^{\mathrm{Ad}}$ & $108,46 \pm 1,29^{\text {Aab }}$ & $110,84 \pm 1,60^{\mathrm{ABa}}$ & $107,48 \pm 1,13^{\mathrm{Abc}}$ & $105,80 \pm 1,15^{\text {Acd }}$ \\
\hline EES+LR & $106,58 \pm 1,68^{\text {Аа }}$ & $109,84 \pm 2,78^{\text {Аа }}$ & $110,68 \pm 2,42^{\mathrm{ABa}}$ & $107,94 \pm 2,69^{\mathrm{Aa}}$ & $106,22 \pm 3,41^{\mathrm{Aa}}$ \\
\hline $\mathrm{NaCl}$ & $105,84 \pm 1,44^{\mathrm{Ac}}$ & $111,74 \pm 1,41^{\text {Aab }}$ & $114,02 \pm 1,90^{\mathrm{Aa}}$ & $108,96 \pm 2,07^{\mathrm{Abc}}$ & $105,24 \pm 3,03^{\mathrm{Ac}}$ \\
\hline PEG & $3,30 \pm 0,38^{\mathrm{Aa}}$ & $4,02 \pm 0,77^{\mathrm{Aa}}$ & $3,60 \pm 0,38^{\mathrm{Aa}}$ & $3,80 \pm 0,52^{\mathrm{Aa}}$ & $3,94 \pm 0,56^{\mathrm{Aa}}$ \\
\hline $\mathrm{PEG}+\mathrm{LR}$ & $3,44 \pm 0,57^{\mathrm{Aa}}$ & $3,30 \pm 0,60^{\mathrm{Aa}}$ & $3,42 \pm 0,37^{\mathrm{Aa}}$ & $3,72 \pm 0,67^{\mathrm{Aa}}$ & $3,70 \pm 0,54^{\mathrm{Aa}}$ \\
\hline EES & $3,38 \pm 0,22^{\text {Аa }}$ & $3,30 \pm 0,63^{\text {Aa }}$ & $3,74 \pm 0,26^{\mathrm{Aa}}$ & $3,64 \pm 0,43^{\mathrm{Aa}}$ & $3,82 \pm 0,25^{\mathrm{Aa}}$ \\
\hline $\mathrm{EES}+\mathrm{LR}$ & $3,82 \pm 0,42^{\mathrm{Aa}}$ & $3,42 \pm 0,53^{\mathrm{Aa}}$ & $3,64 \pm 0,65^{\mathrm{Aa}}$ & $3,74 \pm 0,35^{\mathrm{Aa}}$ & $4,16 \pm 0,37^{\mathrm{Aa}}$ \\
\hline $\mathrm{NaCl}$ & $3,50 \pm 0,20^{\mathrm{Aa}}$ & $3,42 \pm 0,37^{\mathrm{Aa}}$ & $3,16 \pm 0,36^{\mathrm{Aa}}$ & $3,86 \pm 0,35^{\mathrm{Aa}}$ & $3,74 \pm 0,85^{\mathrm{Aa}}$ \\
\hline PEG & $0,60 \pm 0,46^{\mathrm{Aa}}$ & $0,79 \pm 0,12^{\mathrm{ABa}}$ & $0,71 \pm 0,10^{\mathrm{ABa}}$ & $0,71 \pm 0,24^{\mathrm{Aa}}$ & $0,82 \pm 0,19^{\mathrm{Aa}}$ \\
\hline PEG+LR & $1,04 \pm 0,71^{\text {Aa }}$ & $1,37 \pm 0,55^{\mathrm{Aa}}$ & $1,42 \pm 0,35^{\mathrm{Aa}}$ & $0,99 \pm 0,27^{\text {Аа }}$ & $0,95 \pm 0,42^{\text {Аа }}$ \\
\hline EES & $0,74 \pm 0,14^{\text {Aab }}$ & $0,63 \pm 0,26^{\mathrm{Bab}}$ & $0,49 \pm 0,06^{\mathrm{Bb}}$ & $0,82 \pm 0,17^{\text {Aab }}$ & $1,09 \pm 0,43^{\mathrm{Aa}}$ \\
\hline $\mathrm{EES}+\mathrm{LR}$ & $0,71 \pm 0,17^{\mathrm{Aa}}$ & $1,08 \pm 0,66^{\mathrm{ABa}}$ & $0,96 \pm 0,49^{\mathrm{ABa}}$ & $1,12 \pm 0,48^{\mathrm{Aa}}$ & $1,10 \pm 0,33^{\mathrm{Aa}}$ \\
\hline $\mathrm{NaCl}$ & $0,62 \pm 0,09^{\mathrm{Aa}}$ & $1,08 \pm 0,71^{\mathrm{ABa}}$ & $1,04 \pm 0,72^{\mathrm{ABa}}$ & $0,90 \pm 0,28^{\mathrm{Aa}}$ & $1,07 \pm 0,14^{\mathrm{Aa}}$ \\
\hline
\end{tabular}

Means in the same column followed by equal capital letters and in the same row followed by equal lower cases letters do not differ at $5 \%$ level of probability by Tukey test.

PEG (Polyethylene glycol)

PEG+LR (PEG plus lactated Ringer's solution)

EES (enteral electrolyte solution)

EES+LR (EES plus lactated Ringer's solution)

$\mathrm{NaCl}(0.9 \%$ sodium chloride solution)

studied variables, the combination with lactate Ringer's solution (PEG+RL) induced minor changes like decreases of $\mathrm{CHCO}_{3}^{-}$in T12h, compared to T24h, and of BE in T6h and T12h, compared to T24h. Emphasizing that despite the decrease had been significant, the values remained within the reference range (KANEKO et al., 2008), making them of no clinical significance. Moreover, the values promptly returned to baseline levels in T24h (Table 1).

\section{CONCLUSION}

The PEG 3350 electrolyte solution did not interfere with the acid-base balance, and should be consider as therapeutic option for horses that need laxatives. Despite the slight acidifying effect, the proposed enteral electrolyte solution showed to be clinically safe to be used in normal horses. The association of intravenous
Ringer lactate with the used enteral electrolyte solutions or the infusion of intravenous $0.9 \% \mathrm{NaCl}$ solution using doses and infusions rates presented in this study can cause important electrolytes and acid-base imbalances and should be used with caution in clinical cases.

\section{ACKNOWLEDGEMENTS}

To FAPEMIG (Fundação de Amparo à Pesquisa do Estado de Minas Gerais).

\section{SOURCES AND MANUFACTURES}

a Padock NFgel ${ }^{\circledR}$ - Lab Vetbrands

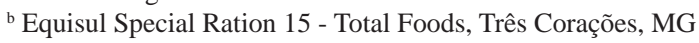

${ }^{c}$ Hiposal 80\% - Total Foods, Três Corações, MG

d Sodium chloride $0.9 \%$ - Texon

e Pidomag ${ }^{\circledR}$ - Baldacci Laboratory, Brazil

${ }^{\mathrm{f}}$ Muvinlax - Libbs 


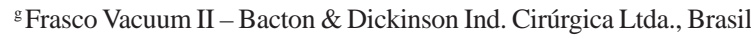

h Single Channel Flame Photometer - FC 180 Model: Celm

${ }^{i}$ Automatic device Alizé - Clinine 150

${ }^{\mathrm{k}}$ Parinex - Hipolabor Laboratory

${ }^{1}$ Venous blood gas i-STAT - i-STAT Corporation, USA

\section{BIOETHICS AND COMMITTEE APPROVAL}

The experimental design was submitted to Ethics Committee of the institution of origin, and was approved by the protocol number 050/2007.

\section{REFERENCES}

ALVES, G.E.S. et al. Tratamento da compactação experimental do cólon maior em equinos: resultados de laboratório e exames bioquímicos. Arquivo Brasileiro de Medicina Veterinária e Zootecnia, v.57, n.3, p.281-287, 2005. Disponível em: <http:// www.scielo.br/scielo.php?pid=S0102...script $>$. Acesso em 21 jun. 2012. doi: 10.1590/S0102-09352005000300001.

ATTAR, A. et al. Comparison of a low dose polyethylene glycol electrolyte solution with lactulose for treatment of chronic constipation. Gut, v.44, n.2, p.226-230, 1999. doi:10.1136/gut.44.2.226.

BARBOSA, P.A.; SZTAJNBOK. J. Electrolyte disturbances. Review Article. Journal Pediatrics, v.75, n.2, p.223-233, 1999.

BLACK, D.A.K. Body fluid depletion. Lancet, v.21, p.305-311, 1953. doi:10.1016/S0140-6736(53)91039-3.

CARLSON, G.P.; BRUSS, M. Fluid, electrolyte, and acid-base balance. In: KANEKO, et al. Clinical biochemistry of domestic animal. 6.ed. San Diego : Academic, 2008. Cap.17, p.529-559.

CLARCK, E.S.; BECHT, J.L. Clinical pharmacology of the gastrointestinal tract. Veterinary Clinical North America Equine Practice, v.3, n.1, p.101-122, 1987.

CLEVELAND, M.V. et al. New polyethylene glicol laxative for treatment of constipation in adults: a randomized, double-blind, placebo-controlled study. South Med J, v.94, p.478-481, 2001.

CONSTABLE, P.D. Clinical assessment of acid-base status: strong ion difference theory. Veterinary Clinical North America Food Animal Practice, v.15, n.3, p.447-472, 1999.

CONSTABLE, P.D. Hyperchloremic acidosis: the classic example of strong ion acidosis. Anesth Analg, v.96, p.919-922, 2003.

DABAREINER, R. M.; WHITE, N. A. Large colon impaction: 147 cases (1985-1991). Journal of the American Veterinary Medical Association, v.206, p.679-685, 1995.

DeMORAIS, H.A.; BIONDO, A.W. Disorders of chloride: Hyperchloremia and hypochloremia. In: DiBARTOLLA, S.P. Fluid, electrolyte and acid-base disorders in small animal practice. 4.ed. St. Louis : Elsevier, 2012. Cap.4, p.80-91.

DeMORAIS, H.A.; DiBARTOLA, S.P. Mixed acid-base disorders. Part I: Clinical approach. Compendium Continuing Education Practicing Veterinarian, v.15, n.12, p.1619-1626, 1993.

ECKE, P. et al. Induced diarrhea in horses. Part 2: response to administration of an oral rehydration solution. Veterinary Journal, v.155, n.2, p.161-170, 1998.
EWASCHUK, J.B. et al. D-lactate in human and ruminant metabolism. Critical Review. J American Society Nutrition Science, v.135, n.7, p.1619-1625, 2005.

FALL, P.J.; SZERLIP, H.M. Lactic acidosis: from sour milk o septic shock. Analytic Reviews. Journal Intensive Care Medicine, v.20, n.5, p.254-271, 2005. doi: 10.1177/0885066605278644.

KANEKO, J.J. et al. Clinical biochemistry of domestic animal. 6.ed. San Diego : Academic, 2008. 904p.

LOPES, M. A. F. et al. Treatments to promote colonic hydration: enteral fluid therapy versus intravenous fluid therapy and magnesium sulphate. Equine Veterinary Journal, v.34, p.505-509, 2002.

MATHEWS, K.A. The various types of parenteral fluids and their indication. Veterinary Clinical North America Small Animal Practice, v.28, n.3, p.483-513, 1998.

PROUGH, D.S.; BIDANI, A. Hiperchloremic metabolic acidosis is a predictable consequence of intraoperative infusion of $0,9 \%$ saline. Anesthesiology, v.90, n.5, p.1247-1249, 1999.

RIBEIRO FILHO, J.D. et al. Hemogasometria em equinos com compactação experimental do cólon maior tratados com sene, fluidoterapia enteral e parenteral. Ciência Rural, v.37, n.3, p.755761, 2007. Disponível em: <http://dx.doi.org/10.1590/S010384782007000300024>.

RIBEIRO FILHO, J. D. et al. Tratamentos da compactação experimental do cólon maior de equinos com hidratação enteral, intravenosa e sene (Cassia augustifolia Vahl). Revista Ceres, v.59, p.32-38, 2012. Dísponível em: <http://dx.doi.org/10.1590/ S0034-737X2012000100005>.

RIBEIRO FILHO, J.D. et al. Hemogasometria em cães com desidratação experimental tratados com soluções eletrolíticas comerciais administradas por via intravenosa. Ciência Rural, v.38, n.7, p.1914-1919, 2008. Disponível em: <http://dx.doi. org/10.1590/S0103-84782008000700017>

RIBEIRO FILHO, J.D. et al. Hidratação enteral em ruminantes e equídeos. Eficiência e baixo custo. Revista Conselho Medicina Veterinária, v.48, p.63-67, 2009.

ROSE, R.J. A physiological approach to fluid and electrolyte therapy in the horse. Equine Veterinary Journal, v.13, n.1, p.714, 1981. doi: 10.1111/j.2042-3306.1981.tb03439.

SAEG. Versão 9.1. Viçosa: UFV, Fundação Arthur Bernardes, 2007. 301p.

SCHILLER, L.R. Clinical pharmacology and use of laxatives and lavage solutions. Journal Clinical Gastroenterology, v.28, n.1, p.11-18, 1999.

STEWART, R.H. Considerations in fluid and electrolyte therapy. In: REED, S.M.; BAYLY, W.M. Equine internal medicine. Philadelphia: Saunders, 1998. p.192-198.

TAM, F.M. et al. Safety and palatability of polyethylene glycol 3350 as an oral laxative in cats. Journal Feline Medicine Surgery, v.13, n.10, p.694-7, 2011. doi: 10.1016/j.jfms.2011.05.017.

ZHANG, D.L. et al. D-lactic acidosis secondary to short bowel syndrome. Postgraduate Medical Journal, v.79, p.110-112, 2003. Disponível em: <http://pmj.bmj.com/content/79/928/110.full>. Acesso em: 18 jun. 2012. doi:10.1136/pmj.79.928.110. 